\title{
Performing protest, articulating difference: environmentalists, Aborigines and the Kuranda Skyrail dispute
}

\author{
Rosita Henry ${ }^{1}$
}

During 1993 and 1994 the Cairns to Kuranda Skyrail became a hot political issue in North Queensland. The responses of the local community to the construction of this passenger cable car through the Barron Falls National Park and the newly listed Wet Tropics World Heritage Area, were varied but quickly became polarised as being either for or against the project. The Skyrail became a heated topic of debate in both the private and public domains, in the homes of local people, in the cafes and bars and other meeting places, eventually spilling out into the streets in the form of demonstrations, and into the rainforest itself in the form of the blockade and direct action by some of the protesters.

In this paper I explore the articulation of different Aboriginal and non-Aboriginal responses to the Skyrail. Although the responses were polarised as pro- or anti- the development, I do not interpret the Skyrail dispute as a simple binary contestation, either of values, world views, ideologies, or primordial loyalties. Nor do I see it as a mere struggle of two opposing social groups, the powerful against the powerless, Aboriginal against non-Aboriginal, greenie against developer, and so on. Rather, I attempt an escape from the categorical imperatives that otherwise constrain interpretation, by focusing my discussion on the discursive fields and practices which produce them. I develop my argument by highlighting a particular moment of protest within the Skyrail dispute. Such moments, I suggest, are the key to a better understanding of how political identities are made. Identities are not given, but are produced situationally. They are not something composed out of the inherent properties of individuals, but are the result of practice. The relationship between sameness and difference is produced and articulated performatively, and it is as such a productive enunciation that the Kuranda Skyrail dispute can best be understood.

I see the Skyrail dispute as a place making situation which is also a public performance of identity. Political identities are made through the "articulatory practice ${ }^{2}$ of

1. This paper is based on fieldwork conducted under the auspices of a small grant from the Australian Institute of Aboriginal and Torres Strait Islander Studies, and forms the basis of a chapter in the author's Ph.D thesis. See also Henry 1995 and Greer \& Henry 1996. 
a discourse of sameness and difference. I am influenced in my perspective by the recent fascination among theorists with exploring the significance of the interplay between self and other in identity formation. ${ }^{3}$ Michael Taussig for example, argues that identity 'has to be seen not as a thing-in-itself but as a relationship woven from mimesis and alterity within colonial fields of representation'.

My focus is on the performative dimension of this interplay between self and other, sameness and difference. I do not mean that identity is merely a matter of selfrepresentation, or a game people play by freely picking and choosing from a pool of cultural substance and then moulding masks to suit themselves. Rather, I take performance as a type of situated social practice by which people politically engage with one another and contest and negotiate the categorical identities that are structurally and historically produced. As Homi Bhabha writes:

Terms of cultural engagement, whether antagonistic or affiliative, are produced performatively. The representation of difference must not be hastily read as the reflection of pre-given ethnic or cultural traits set in the fixed tablet of tradition. The social articulation of difference, from the minority perspective, is a complex, ongoing negotiation that seeks to authorise cultural hybridities that emerge in moments of historical transformation. ${ }^{5}$

Let me hasten to qualify my use of Bhabha here. Firstly, whereas Bhabha uses them synonymously, I make a distinction between 'cultural engagement' and 'social articulation'. My focus is on 'social articulation', that is, on the articulation of situated discursive practices through which place is made and identity constituted. My aim is to offer an analysis of how issues of conflict might be understood other than in terms which take racial and cultural differences as given.

Secondly, I also prefer to avoid the use of the term 'hybridity'. It has the potential to lead one to simply replace an interpretation in terms of binary opposites with one based on a holy trinity. In other words, the 'hybrid' becomes fixed as a third category which merely reinscribes the other two categories (coloniser/colonised) and the privileging of one over the other. As Robert Young writes:

Hybridity in particular shows the connections between the racial categories of the past and contemporary cultural discourse: it may be used in different ways, given different inflections and apparently discrete references, but it always reiterates and reinforces the dynamics of the same conflictual economy whose tensions and divisions it re-enacts in its own anti-thetical structure. ${ }^{6}$

Hybridization however, is often presented as a politically radical means of liberation from past colonial dichotomies. Annamarie Jagose, highlights this in her analysis of the border mestiza figure in Gloria Anzaldua's Borderlands/La Frontera: The New Mestiza.

2. Laclau \& Mouffe 1985, p. 1.

3. See, for example, Bhabha 1994; Fuary 1992; Fuary 1997; Gunew \& Yeatman 1993; Kapferer 1995; Moore 1994; Taussig 1993.

4. Taussig 1993, p. 133.

5. Bhabha 1994, p. 2.

6. Young 1995, p. 27. See also Chow 1994, p. 131. Chow argues that what 'Bhabha's word "hybridity" revives, in the masquerade of deconstruction, anti-imperialism, and "difficult" theory, is an old functionalist notion of what a dominant culture permits in the interest of maintaining its own equilibrium...' 
According to Jagose, Anzaldua promotes the mestiza as the 'harbinger of a global miscegenation and hybridization which eliminates forever the possibility of difference and separation'. ${ }^{7}$ Bhabha himself however would not agree. For Bhabha hybridization is not an escape from colonial power. Rather it is the product of colonial power and as Jagose points out in harmony with Bhabha:

...any prioritization of the mestiza must not be on account of her alleged ability to secure a space beyond the border's adjudication of cultural difference but on account of her foregrounding of the ambivalence which enables even as it destabilises the colonial relationship. ${ }^{8}$

On another front, Nicholas Thomas takes Bhabha to task for not adequately theorising heterogeneity in colonial discourse. Thomas questions Bhabha's view of colonial discourse as a 'singular and definable entity'. ${ }^{9}$ Thus, hybridization, as constituting an active moment of resistance, may not be universal but may be specifically a product of British colonial discourse, in itself not a 'unitary construction' ${ }^{10}$

Hybridization, for Bhabha, is colonialism's construct but it is a construct which resists its maker. Because it unravels as much as it knits dominant cultural power, it becomes an active moment of resistance. However, it is precisely this notion, that hybridity is a product of colonial power, that Thomas finds problematic. Thomas would grant to the colonized greater autonomy in their 'enunciations and strategies', an 'empowered practice' for which, he argues, Bhabha's approach does not allow. ${ }^{11}$ However, Thomas's perspective is itself limited. His culturalist focus makes for a tendency to underestimate the oppressive nature of colonial regimes.

With these reservations about the concept of hybridity in mind, I find Bhabha's notion of 'active moments of resistance' enlightening, particularly his understanding that such moments are ambivalent ones in which sameness and difference are articulated, and political identities are made. The Kuranda Skyrail protest scene I describe below is, I argue, such an 'active moment'. I do not see it as productive of some new hybrid identity category. Rather, it is a productive moment of strategic action and resistance. Here I am in sympathy with Thomas who, following Bourdieu, advocates 'an understanding of a pluralized field of colonial narratives, which are seen....as signifying practices rather than elements of a code ${ }^{\prime}{ }^{12}$ I stress however that these signifying practices are situated practices and not simply cultural representations somehow remote from the colonial political regimes that have spawned them. As John Peters points out:

The improvisation of identity is wonderful if you have the cultural and finance capital to cushion you against the traumas of post-modernity, but most of the human species still lives out its days in localized spaces, dependent in various ways on the people they have known for years. The means of making one's identity a poetic work are inequitably distributed... We should neither drain the concept of culture of its ties to place and matter nor freeze it into absolute identity. ${ }^{13}$

\footnotetext{
7. Jagose 1993, p. 213.

8. Ibid., p. 224.

9. Thomas 1994, p. 45.

10. Ibid.

11. Ibid., pp. 58-9.

12. Ibid., p. 8.

13. Peters 1997, p. 91.
} 
My focus on a particular localized moment of protest answers Thomas's call for a 'historicized, ethnographic approach' to colonial discourses. ${ }^{14}$ I attempt to offer a means by which social conflict might be understood other than in terms of given racial and cultural differences. It is in particular in the study of human environmental relationships that the complex interface between indigenous peoples and others tend to be reduced to a matter of cultural difference, or of contrasting environmental values. ${ }^{15}$

\section{Protesting the Skyrail}

Skyrail runs from the bottom of the range near Cairns, through the Barron Falls National Park and the Wet Tropics World Heritage Area, to Kuranda. Final state government approval for the construction of Skyrail was given in November 1993 and it was officially opened on 1 September 1995.

The concept of a Cairns-Kuranda cableway had been around since 1987 when a company called Global Research Pty Ltd. (the forerunner to Skyrail Pty Ltd) began investigating its feasibility. In June 1988 Queensland's Bjelke-Petersen government gave approval in principle for a cableway. Local residents opposed to the development had only just begun to gather forces when in December 1988 the designated 'Wet Tropics' area, through which the proposed cableway was to be constructed, was successfully listed as a World Heritage Area. The Queensland Government took a High Court action against the listing but in December 1989 the newly elected Labor Government withdrew this action and deferred the cableway issue until a Wet Tropics World Heritage management regime could be established. ${ }^{16}$ Once the World Heritage area was declared, the urgency for people to protest against the cableway was apparently removed and it was not until 1993 that the issue resurfaced in the public consciousness. $^{17}$

In anticipation of the government go-ahead, a group of concerned people, from both Cairns and Kuranda, met and formed an anti-Skyrail action group which they named PAKS (People Against Kuranda Skyrail). This group included not just environmentalists but also other residents of the Kuranda area worried about the effects of the Skyrail on their lifestyles. It included representatives from the Djabugay Tribal Aboriginal Corporation, the Wilderness Society, and the Cairns and Far North Environment Centre (CAFNEC). The group began to distribute a newsletter to keep people informed about the progress of its campaign. In response, some anonymous pro-Skyrailers put out their own newsietter-a form of 'seditious laughter', 18 to undermine the PAKS cause. They called themselves PAPAKS (People against People against Kuranda Skyrail). Their first newsletter began in the following vein:

14. Thomas 1994, p. 8.

15. See, for example, Strang 1997.

16. I am indebted to Bruce White for his A Chronology of Documents, Letters, Media, and Events Telling the Story of How It Is that a Cairns-Kuranda Cableway Got to Be Constructed in a Djabugay Cultural Landscape, unpublished manuscript submitted to Mr George Menham (General Manager, ATSIC), reporter under $\mathrm{s} 10$ of the Aboriginal and Torres Strait Islander Heritage Protection Act 1984 (Cwlth) 1995.

17. Henry 1995; Greer \& Henry 1996.

18. Butwin 1978. 
Our mandate is to oppose the Greenie, Leftie, Pinko, Dole-bludger, Hippie, Feral, Artie Fartie, Mabo Do-gooder minority factions that will stop anything just for the sake of stopping it...PAPAKS are real world people who don't scoot around the rainforest lustfully hugging trees, but in fact hate and detest trees-just look at what the rotten, stinking trees did to Sydney recently-trees are killers!

The PAKS meetings throughout 1994 were regularly attended by a significant number of Kuranda Aboriginal people. I say significant because it is extremely rare to find Aboriginal people in Kuranda attending meetings which are driven by members of the wider non-Aboriginal community. Of a total of 76 people listed individually by name on the mailing and work group list of PAKS, 11 are Aboriginal and further newsletters were sent out on request to the Aboriginal settlements at Mantaka, Kowrowa, and Mona Mona. The formation of PAKS meant that Aboriginal people who were against the Skyrail could access allies in the non-Aboriginal community. PAKS organisers were just as keen to harness the support of Djabugay people against the Skyrail as Djabugay people were to use PAKS. As one woman put it to me,

They [PAKS] needed our support as well, so I think it worked both ways. They came in asking for our support you know really, and we helped them. So we helped each other... ${ }^{19}$

A cultural awareness workshop was arranged in Kuranda to promote goodwill and understanding between Aboriginal and non-Aboriginal protesters, which I attended as an observer. A trained facilitator from one of the environmentalist groups organised the workshop at which a Djabugay Elder talked about the removal of her family from the Kuranda area to Mona Mona Mission in 1916, of her life growing up on the Mission, and the meaning of the rainforest to her people. The workshop facilitator also arranged a visit by women protesters to the old Mona Mona Mission site and a partnership system was formed there, in which non-Aboriginal women and Aboriginal women were encouraged to form pairs so that they could support each other in their combined campaign against Skyrail.

\section{Direct action: spatial enunciations of protest}

PAKS members were not united on what form their protest against Skyrail should take. Many thought that PAKS should confine itself to attempts at raising public awareness through media coverage, public displays, peaceful marches, and letters, petitions, and submissions to the state and federal governments. Others thought that this was not enough and that direct action, such as blockades at the various Skyrail tower construction sites, was required. To this end 'non-violent direct action' training was undertaken by some of the members and a separate group was formed, the Barron Gorge Wildlife Action Group. Members of this group remained part of PAKS but engaged in independent actions to physically obstruct the construction of the cableway. Direct action included sitting within the boundaries of construction sites, erecting a bamboo platform at one of the tower sites to stop Skyrail's helicopter from moving equipment from the site, dressing up as endangered rainforest species, building a set and performing a skit inside the office of the Department of Environment and Heritage, and above all, 'tree sitting'. What the protesters called 'tree sits' involved volunteers climbing particular

19. Personal interview, 10 November 1995, Kuranda. 
trees to prevent loggers from continuing to clear the tower sites. The tree sitters were supported by a ground crew which provided them with food and other requirements. One protester lasted 208 days in a tree before he was tricked into allowing police, posing as a television crew, onto his platform. He was removed by police using a block and pulley system and the tree was then felled. ${ }^{20}$

Aboriginal people of Kuranda also engaged in direct action against the Skyrail. Dancers from the Tjapukai Dance Theatre joined the protest demonstrations by performing their connection to the country with music and dance. Others painted placards and joined the street marches organised by PAKS, demonstrated at the tower sites, and supported the tree-sitters by bringing them food. Some Aboriginal youths even took their turn sitting in trees, although they tended not stay in the forest overnight.

Aboriginal views on the Skyrail however were as divided as the views of the general population. Some Aboriginal people in Kuranda saw it as an avenue for employment and in May 1992 the Chairperson of the Mona Mona Aboriginal Corporation wrote to the developer asking for a meeting to discuss how a proposed new agencythe Djabugay Ranger Land Management, Conservation and Protection Agency could assist Skyrail Pty Ltd. ${ }^{21}$ These differences in response to the Skyrail appear to correspond to already entrenched patterns of conflict among various factions in the Kuranda Aboriginal community, represented partly by the various incorporated bodies and the divide between the so called 'historicals' (that is, people brought into Mona Mona mission from other country) and 'traditionals' (the Djabugay), but it is not quite as simple as that. The responses to the Skyrail are not adequately explained in such categorical terms.

What is revealed in both Aboriginal and non-Aboriginal responses to the Skyrail is an interrogation and undermining of the authority of categorical identities. Political manoeuvring with regard to the Skyrail, I argue, provided a forum for dismantling their hegemony.

To illustrate this more clearly I will describe a three minute scene from an antiSkyrail protest at one of the Skyrail tower sites captured on video by one of the protesters. There were no media personnel at the site, only protesters, police and Skyrail logging contractors. In the video clip one of the Aboriginal protesters points out that this is not a performance for the media and therefore that they are not just putting on a show. 'We don't need no media. There's no media here. Our protest is from our heart and our heart is here'.

\section{A moment in the performance of protest}

The protesters mainly comprise women and children, both Aboriginal and non-Aboriginal. They have seated themselves within the boundaries of a site to be cleared in the rainforest for one of the Skyrail towers. A number of the non-Aboriginal women and children are attached together around trees on the site with 'super-glue'. The police walk the Aboriginal protesters off the site which is cordoned off with yellow tape. The Aboriginal protesters then stand outside the tape barrier protesting verbally as the

20. Caims Post, 11 January 1995, p. 1.

21. White 1995, pp. 22-23. 
police physically remove, in some cases carry and drag, the non-Aboriginal protesters from the site. Some of the young girls are crying. It is apparent that at least one of them is in pain. They indicate that their super-glued hands had been torn apart by police.

The protesters then stand outside the barrier, with the police and the loggers within, watching the loggers start to cut the trees. The sound of chainsaws almost drowns out their voices as the protesters shout out to the police and the loggers.

I suggest that this scene represents a performative moment in which social inclusion and exclusion, sameness and difference, are articulated. It is in such moments that identity is constituted, place is made, and community defined. In this scene we see and hear Aboriginal women establishing their difference by calling on the historical specificity of their experiences to be recognised by the police and the loggers:

The Government wants us to shut up. We're like a herd of cattle. They herd us here and there on missions...Learn your history. We're the ones that suffered, not you. You don't even know our history.

On the other hand, we also hear them asserting their sameness-- 'We're Australians. We're all Australians here'. We see and hear them defining the idea of community, in the face of the state hegemonic power represented by the police and the loggers. A woman calls out to a distressed young non-Aboriginal protester by name and puts her arm around her to comfort her, while claiming to her audience of police, loggers and other protesters:

That's how much we know our locals in Kuranda. We're on first name basis. We mix. This is what you call caring. I'm loving up a white girl. We care for one another. We're here for one another. We're not here for ourselves.

This protest scene is indeed an articulatory moment-a moment in which place and identity are constituted. This performative engagement of the ideas of sameness and difference challenges and resists the entrenched binary oppositions of dominant 'games of truth' ${ }^{22}$

\section{A game of truth}

The initial task that PAKS set itself was a 'fact-finding' one. As noted in the PAKS Newsletter, 'most members of our group were assigned fact-finding tasks on which they will report at our next meeting' ${ }^{23}$ In February 1994 volunteers were called on to survey the Skyrail tower sites and count trees within $30 \mathrm{~m}$ from each tower site. This is an indication of the form of discourse in which the debate was expressed. Much of the debate was waged in terms of disputed 'facts'. How much rainforest would actually be destroyed? Was it a fact that the total area to be cleared during the construction of the Skyrail would only be about half a hectare, as was claimed by members of the pro-Skyrail lobby group, or would the construction in fact necessarily entail swathe clearing? What in fact, if any, were the rainforest plant and animal species that would be adversely affected by the Skyrail? Was it a fact that the rainforest was safe from further destruction due to possible accidents during the construction phase? Was it a fact that the Skyrail would lead to fewer buses travelling up and down the range, thus relieving

22. Foucault 1988, p. 16.

23. PAKS Newsletter, 3 October 1993, p. 1. 
Kuranda of some of the pollution and congestion caused by their parking in the village? Was it a fact that the Skyrail would actually result in greater protection of the rainforest by replacing more damaging walking tracks, or would it in fact simply supplement the already existing tracks and spawn the creation of new ones? Were there in fact Aboriginal sites of significance in the path of the Skyrail? In sum, the debate was waged in positivist terms, that is, people debated about what was true or false according to what were perceived as objectively provable facts and they called for environmental and social impact studies to be done to establish the truth or otherwise of the factual claims being made.

Again and again the pro-Skyrail lobby attempted to make the anti-Skyrail protesters look foolish by demonstrating that they had got their facts wrong. The article by freelance journalist Michael Sourial entitled 'Protesters, credible or farcical?' in the Cairns Post is a good expression of this discourse of the literal-minded. ${ }^{24}$ Sourial argues that the actions of the protesters are farcical and he uses a particular action by an individual protester to support his case. This action involved one of the protesters supergluing her hands together around a tree at one of the tower sites. Sourial writes,

The 'super-glue' incident was one of the true low points for this protest which has been marked by embarrassment. The protesters now, incidentally, deny that the young lady in question glued herself to the wrong tree, so let me clear up the doubt once and for all. I was there that day at Tower Site 5 and that protester definitely glued her arms around a tree which was neither slated to be cut, nor in the way of any of the work being done. She may as well have glued herself around a tree in Botswana for all the trouble she caused.

Yet, the authenticity of human action is not simply a matter factual accuracy. What Keith and Pile wrote about the declaration of 'nuclear-free zones' applies, I argue, equally to the anti-Skyrail case.

Assessed in the spirit of literalism, such designations were always manifestly absurd-given the failure of the contemporary nuclear device to respect borders...So how should a nuclear-free zone be judged? As true or false? As real or metaphorical? As authentic or unauthentic? As true as a burning breast or as false as a bleeding heart? ${ }^{25}$

By her act the protester admits she did indeed intend to prevent that particular tree from being destroyed. ${ }^{26}$ Both the pro-Skyrailers and the anti-Skyrailers were enmeshed in a game of truth which required them to legitimise their positions by resorting to what Lyotard, following Wittgenstein, calls 'the language game of science' ${ }^{27}$

The Djabugay protesters too were swept into this game in order to legitimate their native title claims. They had responded independently of PAKS and, on another front by lodging a claim for the Barron Falls National Park with the Native Title Tribunal. The Djabugay Tribal Aboriginal Council (DTAC) ${ }^{28}$ had written already in October 1991 to

24. Sourial 1994, p. 8.

25. Keith \& Pile 1993, p. 10.

26. Personal interview B3, January 1996, Kuranda.

27. Lyotard 1984, p. 28.

28. The Council was incorporated on 7 July 1992 and became the Djabugay Tribal Aboriginal Corporation. 
the State Minister for Environment and Heritage, and the Regional Director of the Department of Environment and Heritage, among others, asserting that the Djabugay are 'traditional owners' of the area and that the 'Barron Gorge is part of Djabugay spiritual heritage which should not be desecrated and spoiled'. ${ }^{29}$ However, the developers were considered, by the Department, to have discharged their responsibilities and obligations under the relevant cultural heritage legislation, the Cultural Record (Landscapes Queensland and Queensland Estate) Act 1987 (Qld) (the Cultural Records Act), and the Skyrail was allowed to go ahead.

A cultural heritage survey prepared for Skyrail under the legislation had concluded that there were no sites of cultural significance along the Skyrail route. Many Djabugay people were outraged by this report. They considered that it effectively 'denied them recognition of the continuity of their relationship with the country which the Skyrail traversed, and therefore their contemporary identity as traditional owners of this area' ${ }^{30}$ However, the response of DTAC expresses the hegemony of the scientific paradigm. The Chairperson of DTAC sent a letter to various government ministers and department directors questioning the 'professionalism and qualifications' of the consultant and noting that he was not a qualified archaeologist. ${ }^{31}$

In particular, the dispute focused on a number of scarred trees and stone arrangements. Although younger Djabugay people had been previously unaware of their existence, they did not doubt that these were their sites and that if they had to produce tangible evidence of their heritage, particularly for the purpose of establishing native title, then here it was. As one young woman put it:

Then came the time to go and visit the sites...I had only studied these things. The actual experience now to see it first hand...that was what gave me the drive. We had to protect that. Just the feeling, and I still get that feeling that has more or less kept me going all this time...It [the sites] was just another thing to reinforce it, that it is really true. I could actually say it was true, it was real ${ }^{32}$.

Four separate archaeological opinions were requested by Djabugay people in the hope that the archaeologists would provide the scientific proof required to establish the significance of the sites and therefore the overall significance of the Barron Falls National Park.

The debate was a positivist one waged in terms of scientifically provable fact. Were the scarred trees in fact Aboriginal shield or burial trees? Were the rings of stones in fact Aboriginal sites, or were they made by more recent visits by 'whitefellas' to the area, perhaps bushwalkers or timber cutters, or were they just old 'hippy' camps, as was one suggestion from the pro-Skyrail lobby group? Since the Aboriginal identity of the sites could not be established archaeologically, and Djabugay people could not make their voices heard within the dominant language game of science, they decided to enlist the help of the federal government by turning to the Aboriginal and Torres Strait Islander Heritage Protection Act 1984 (Cwlth). A reporter, Mr George Menham, was appointed in accordance with section 10(4) of the Act to prepare a report for considera-

29. White 1995, p. 15.

30. Greer \& Henry 1996, p.20.

31. White 1995, p. 53.

32. Personal interview, 10 November 1995, Kuranda. 
tion of the Minister for Aboriginal and Torres Strait Islander Affairs. Djabugay attempted to resist site based definitions of heritage by articulating their claims to the reporter in terms of a concept of 'cultural landscape'. The following quotation is an example of the kind of knowledge of a wider living landscape used by Djabugay to try to escape demands of the discourse of science, and to thus evidence the Aboriginal significance of the National Park and places along the Skyrail route. A Djabugay ranger explains what he told the reporter:

Yeah,...I told him also of how Damarri is now sleeping. I told him if he goes back in to the Cairns area, from Machans Beach turn off, Holloways, all of them, Yorkeys Knob, and you're looking backwards and forwards and you look at the skyline, just of the mountains, you can see Damarri lying down. I told of Bunanda, how the water fairy came about, and how they used to climb up one side of the mountain of Red Peak and go down the other side where now they are building Skyrail-where the Yirriganydji could be, and the Djabugandji all camped below, once, when the Barron used to run that way. I told him of the camp there. Also the one in Woompera farm (Warrama) there, the camp there. Go back from Warrama, around the lookout; come into Mount Saddleback; from there along McAlaister Range (my area); walk back into Mona Mona; all that run. My grandma, being associated with that Red Peak and that place-travel along that ridge back into Mona Mona, and then back to Oak Forest. That's Guruminya side, you know. There's two sides. One Guruminya and one Gurubana. ${ }^{33}$

By phrasing their claims in terms of this kind of 'narrative knowledge ${ }^{34}$ and asserting a landscape based cosmology, as opposed to a site based one, Djabugay were asserting that the 'particular significance' 35 to them of places along the Skyrail route was based not just on those places as fixed and objectifiable markers of given past events, but on a continuing process of being in relationship with those places.

Kuchler makes a distinction between landscapes of memory, and landscapes for memory. A landscape is a landscape of memory when it is taken to be an aide memoire, a given surface for the inscription and capture of memories, whereas to take landscape as memory means that it is seen as a product of the process of remembering 'which is forever being transformed'. ${ }^{36}$ I suggest that by their use of the concept of cultural landscape in connection with the Skyrail report Djabugay meant landscape as memory, landscape as a lived memory producing experience.

Barbara Bender notes that landscapes are not given but 'are created by people through their experience and engagement with the world around them' ${ }^{37}$ According to Howard Morphy in Arnhem Land people learn about their landscape through the 'experiences and associations of their lives', ${ }^{38}$ by travelling through the land and by events such as birth, marriage and death. It is the lived experience of these events which

33. White 1995. Page 84 of the document in an unpaginated appendix transcribed by White from an interview he conducted, immediately following a visit to Kuranda by Mr George Menham, 17 May 1995. Damarri is an ancestral being. Guraminya and Gurabana are moiety names.

34. Lyotard 1984 compares and contrasts 'narrative' and 'scientific' knowledge.

35. The Aboriginal and Torres Strait Islander Herutage Protection Act 1984 (Cwlth) requires that a report under section 10(4) deal with the 'particular significance of the area to Aboriginals'.

36. Kuchler 1993, p. 104.

37. Bender 1993, p. 1.

38. Morphy 1995, p. 204. 
creates the particular moments in which the landscape of the Yolngu is made visible. Djabugay landscapes can also be understood in such terms. Places are absent unless events give them a presence. In the contemporary context such events include political moments, like the Skyrail dispute. The authenticity of Djabugay claims to country was questioned within a language game of science which required the archaeological identity of particular sites to be established. However, cultural authenticity cannot be proved scientifically. Authenticity, I argue, can only be established outside of this game of truth, by the contemporary practices of remembering which make present the Aboriginal continuity of the landscape to Aboriginal people themselves. As one woman put it:

And actually, when we went further into the rainforest we came across other things. Elders started releasing what they knew about it. It started a whole awakening. 39

It is their own sensory experiences of, and engagement with the country, and that of their forebears, upon which Djabugay base their claims. Landscape is a living memory domain for an ideology of a continuity of being in place. Djabugay people express their connection with land in terms of their feelings for, and experience of, a generalised domain alive with spiritual forces and beings, and having an agency of its own. For example, when the Cairns/Kuranda train narrowly escaped a rock slide on the track, two Djabugay women elders, whispered that the rock slide was actually Damarri's ${ }^{40}$ response to the Skyrail. ${ }^{41}$

However, many of the non-Aboriginal protesters think of the environment similarly. They either anthropomorphise nature itself (usually as female) or think of it as alive with spiritual beings. One protester said that she firmly believed that that forest was alive with Aboriginal ancestral spirits. On one occasion while she was in the rainforest during the night or in the very early hours of the morning, she saw a tall Aboriginal warrior. She had heard stories from Aboriginal people of the existence of beings they call 'small men', so she had wondered why he was so tall but 'one of the Murris' told her later that there were also 'tall men'. This protester also related how she saw a giant cassowary appear behind her and on another occasion a cassowary head and then the face of an Aboriginal man emerging from a tree trunk. She said she was later told by Aboriginal people that their ancestors sometimes manifest themselves as cassowaries. She then said that the forest comforted her by telling her that it would look after itself against the Skyrail. Nature would have 'her' own revenge. As proof she, and another protester, recounted the number of times, since beginning operations, that the Skyrail has been 'out of action' due to storms and lightning strikes. ${ }^{42}$

39. Personal interview, 10 November 1995, Kuranda.

40. Damarri is also called Bulurru. Bulurru is how Djabugay refer to the Dreaming. Storywaters, or locations associated with the Dreaming as well as the ancestral beings associated with them are known as Bulurru. Bulurru is considered to be the source and condition of all life and is ever-present in the land and people'. Quinn 1992, p. 16. Some Djabugay people today think of Bulurru as 'our God', as distinct from the Christian God they were taught to worship in the mission. Others think of Bulurru as simply the Djabugay name for the one and only God, also the Christian God, which they have always worshipped.

41. Personal communication, 18 June 1995, Kuranda.

42. Personal interview, 24 January 1996, Kuranda. 


\section{Environmentalists and Aborigines}

In general, environmentalists think of themselves as being part of a political and moral crusade for a better world. Environmentalism has been characterised by Charles Rubin as being the heir to the anti-slavery and temperance movements and as therefore part of an ongoing saga of evangelical reform. He writes,

Indeed it is not far off the mark to say that environmentalism is the temperance movement of our time. We know that it wants to save the earth. But we forget just how much it wants to save us from ourselves. ${ }^{43}$

Environmentalism is thus based on a universalistic view of the world. Although environmentalists might 'act locally' they assume a common humanity and common, unilinear human destiny. What are thought of as 'traditional' Aboriginal ways of relating to the environment are celebrated as a contemporary expression of the way all humans must have once lived.

Environmentalists have turned to indigenous beliefs around the world, for inspiration and guidance on how to formulate an alternative human environmental relationship. Thus, indigenous people are seen as a source of guidance for alternative ways of being in nature, and have been romanticised as the 'first true conservationists'. ${ }^{44}$ In other words, as David Trigger puts it, environmentalists have 'co-opted alleged indigenous ethics regarding land use to their own cause', 45

A number of writers have discussed the political relationship between environmentalists and Aborigines in Australia. ${ }^{46}$ According to Julie Marcus the celebration of the traditional ways of life of Aboriginal peoples by environmentalists and new age mystics actually operates to further dispossess them. She argues that new age mysticism regarding Uluru is driven by universalising sentiments that deny the unique identity of Aboriginal beliefs. As Marcus puts it:

... attempts to tap into the power of the Rock are seen by local Aboriginal people as simply more of what has gone before-now settlers are mining Aboriginal culture rather than the land itself. ${ }^{47}$

Marcus and others view this as 'cultural appropriation' ${ }^{48}$ Environmentalists are seen as having appropriated Aboriginal culture and environmental values to further their own political cause. The celebration of indigenous environmental ethics is thus seen to be part of a primitivist discourse operating to the disadvantage of Aboriginal people. ${ }^{49}$

On the other hand, these new age values can also be turned around to serve indigenous interests. The concept of traditional culture, or notions of indigenous environmental values and knowledge, have become tools by which indigenous people all over the world can assert their rights in the contemporary context of nation state and international politics. For example, according to Terence Turner, when he first started field

43. Rubin 1994, P. 10.

44. Sackett 1991.

45. Trigger 1996, p. 55.

46. Anderson 1989; Burnam Burnam 1987; Cuthbert \& Grossman 1996; Jacobs 1994; Marcus 1996, 1997; Sackett 1991.

47. Marcus 1997, p. 46.

48. Marcus 1997. See also Jacobs 1994 and Lattas 1997.

49. See Sackett 1991 and Marcus 1997. 
work among the Kayapo in 1962, they were living in a village under the 'protection' of the Brazilian government's equivalent of Queensland's Department of Aboriginal and Torres Strait Islander Affairs and were dependent on this department and the missionaries. According to Turner, at this time the Kayapo were not self-consciously aware of the particular differences of their cultural practices in relation to other peoples in Brazil. To them their ceremonies and social institutions were simply the way they had always done things. As Turner notes:

They had, in short, no notion that their assemblage of received customs, ritual practices, social values, and institutions constituted a 'culture' in the anthropological sense, nor any idea of the reflexive role of that culture in the reproduction of their society and personal identities. ${ }^{50}$

A quarter of a century later when Turner returned to do further research and ethnographic filming in the area it was another story altogether. Turner found 'a new level of cultural awareness and self-consciousness'. Many Kayapo had begun to use the Portuguese word 'cultura' as well as the Kayapo word that comes closest in meaning, kukradja, as meaning 'a particular body of customary practices and lore which require selfconscious effort to preserve and reproduce' and 'concerted political action'. 51

The Skyrail dispute provides an example of the process of development of such a 'new level of cultural awareness and self-consciousness' in the Australian context. It is a case of Aboriginal people actively and very strategically allying themselves with environmentalists in order to resist the powers of oppression. ${ }^{52}$ Celebrating the idea of culture thus becomes a means for indigenous people to negotiate benefits for themselves within the context of contemporary political and economic relations which would otherwise leave them powerless. It is not simply a matter of environmentalists appropriating Aboriginal culture. Far from being helpless victims, Aboriginal people are active political agents. In the Skyrail dispute, Djabugay people forged an alliance with other protesters as a useful political strategy. Environmentalist discourse, and the valuing of traditional culture and of their status as the original environmentalists became a means for Djabugay to assert native title and heritage rights in the contemporary context of nation state politics. The Skyrail dispute also provided Djabugay with a means of asserting a unique identity as rainforest people in a context of an homogenizing stereotype of Aboriginality which contributes to their oppression. Andy Duffin, the chairperson of the Djabugay Tribal Aboriginal Corporation is quoted in the Courier Mail as saying that 'it is the rainforest which keeps the Djabugay people going', and that 'their existence would fall apart without those forests'. ${ }^{53}$ A Djabugay woman explained her involvement in the anti-Skyrail protest similarly :

This rainforest, that's where our foods are; that's where our people lived. They protected the area; they took care of it; and we have the same responsibility. But it sort of goes deeper than that again, that feeling that we got that we had to protect what rainforest is left; because you go into the future, you know. We tell our chil-

50. Turner 1991, p. 294.

51. Ibid., p. 304.

52. Another example is the sucessful resistance to the building of the Todd River Dam in Central Australia. See Jacobs 1994.

53. Courier Mail, 28 May 1995, p. 1. 
dren that we are the rainforest people. If there is no rainforest, you know, how are they going to believe that we are the rainforest people? They'll be asking what is a rainforest?...We are the rainforest people. I mean that was our survival, that rainforest, you know. That will continue to be our survival. ${ }^{54}$

The fact that they had their own political agenda does not mean that Djabugay were not genuine in their dealings with the other protesters. Arguments which suggest that people are using culture as a political tool, sometimes have undertones of cynicism. It is assumed that if something is political, it must therefore be unauthentic. However, I see political practice as part of the fullness of human being in the world. It is not unauthentic practice, and neither is the way indigenous people come to use the concept of culture. Similarly, I do not wish to appear cynical about the intentions of the nonAboriginal protesters. An environmentalist discourse, which sought to establish the moral legitimacy of the protesters by romanticizing indigenous cultural practices and relations with the environment, was indeed evident in the Skyrail case. However, many of the environmentalists were also very sympathetically aware of the historical oppression and contemporary social and economic plight of Djabugay people. They hoped for the success of the Djabugay native title claim, not just because they believed that this would somehow put a halt to the construction of the Skyrail, but also out of a genuine sense of fair play. When Djabugay people eventually came to an agreement with Skyrail Pty Ltd, there was disappointment among the environmentalists but few recriminations. The Skyrail was being built in spite of their protests and they respected Djabugay people's realization that they could not fight this 'big monster' and therefore should focus on securing the best economic deal they could 'for the future' of their children. ${ }^{55}$

This is not to say that there were no tensions between Aboriginal and non-Aboriginal protesters. After the Cultural Awareness Workshop, an agreement was made that in order to have the Aboriginal voice heard, the non-Aboriginal protesters would refuse to speak to the media unless they first interviewed Aboriginal spokespersons. Although made with good intention, the agreement did not last long, however, because Aboriginal spokespersons were not always available when the media arrived, and environmentalists became frustrated at missing good opportunities for press coverage.

Even though one of the elders reflected that he was suspicious about the true motives of the environmentalists and whether or not they were in genuine support of the native title claim, most Aboriginal people saw the non-Aboriginal protesters as primarily working to help their fight for land rights. In fact, one woman referred to the protester who sat up a tree for 208 days, as 'a hero for Aboriginal people'. ${ }^{56}$

However, the universalist tendencies of environmentalism were well articulated in a speech delivered by one of the key participants in the anti-Skyrail campaign during a rally:

As a member of the local community, this is our forest, as a citizen of Australia, this is our National Park, and as a member of the international community this is

54. Personal interview, 10 November 1995, Kuranda.

55. Comments made by a Djabugay participant in a workshop organised and facilitated by the author on 'Responses to Development in the Kuranda Area', 26 June 1995, Kuranda.

56. Personal communication, 3 January 1997, Kuranda. 
our World Heritage, not the exclusive property of Sky-Rail Limited. (emphasis in original)

These sentiments are also expressed in the slogans carried by the protesters-'Economy poisons Ecology', 'Parks and People First Molly, Not Developer's Fees', and 'No Development in World Heritage'. They voice not only the perceived incompatibility between environmental values and economic development, but also the conflict between individualism and communalism, private ownership and the commons. The protesters' placards, I suggest, can be seen as statements of communal title. They voice the protesters' reaction against what was seen as private appropriation of the commons. In contrast, through the native title claim and their direct protest action, the Djabugay were claiming the national park, not as common land, but as their land. The placards of the Djabugay protesters could be read as symbolic title deeds-'Skyrail Garri, Bulurru'-a claim legitimised by Bulurru,'...the source of life...the Good Spirit that protects life and Law $^{\prime} .57$

Although Djabugay were claiming the Skyrail land as their land, and non-Aboriginal protesters were claiming it as belonging to all the world, the inconsistency does not appear to have been clearly recognised by either group. Perhaps this was because Aboriginal and non-Aboriginal protest against the Skyrail was expressed in terms of environmental values with which both groups readily identified, values which require the preservation of the rainforest. As an Aboriginal elder said in the Cultural Awareness Workshop:

...what I mean by the trees, those trees are our culture too...we don't like to see those trees being cut down and the ground, the bulldozers running over it. That's what I call desecration to the land you know.

Moreover they held in common other objections against the Skyrail. Although there were some anti-Skyrail protesters who were not locals, and the blockaders were joined by environmentalists from the south of Australia and even from overseas, most of the protesters were, in fact, residents of the area. For them, Skyrail did not simply pose a threat to the rainforest, whatever the cultural basis on which it might be valued. It also stood for an increased tourist threat to this embattled local community. Both Aboriginal and non-Aboriginal residents of Kuranda were already feeling that the 'village in the rainforest' was no longer theirs. It had been slowly appropriated by developers for the use of tourists. As an Aboriginal woman said in the moment of protest examined above:

We used to roam those bloody streets in Kuranda. And where now?...Kuranda's polluted with tourists.

Loss of control over definition of place means loss of ability to define self. Skyrail provided the site for the spatialized politics that might enable people to reclaim their home place.

\section{Conclusion}

In this paper I have attempted to avoid a culturalist approach which reduces contemporary political relationships between Aboriginal and non-Aboriginal people to given cultural differences, or contrasting environmental values. Although the protesters used

57. Duffin \& Brim, p. 5 . 
'rhetorical strategies which drew upon categorical and/or stereotypical identities', 58 rather than simply taking these categorical identities as given, I have focused my discussion on the discursive fields and practices which operate to produce them. One such discursive field is the language game of science.

I have argued that Aboriginal and non-Aboriginal protesters were caught up in the same game of truth, a game which constrained them to wage their dispute with government agencies and Skyrail developers according to the universalising claims of science. Within the terms of this game their assertions about identity in place, and connection to country, were inevitably made to look foolish.

Even though Skyrail may have been debated in terms of scientific facts, the underlying force driving the dispute really had nothing to do with fact. It was not about right and wrong trees, or authentic or unauthentic Aboriginal sites. Rather, it was about 'burning breasts' and 'bleeding hearts'. ${ }^{59}$ It was an assertion that there are different experiences of being in this world, ones which refuse to be muted.

The Skyrail dispute was an expression of a particular mobilisation of place and identity. At issue was the way in which people, constitute identity and difference in terms of place, that is, the tie between people and place, symbolically expressed, I have suggested, by the protester's physical attachment of herself to the tree. ${ }^{60}$ Such performances/spatial enunciations make their own statements, ones which attempt to escape the domination of the 'language game of science', and thus to give voice to other ways of being.

Although Skyrail protesters received some support from national and international environmentalist groups, and they drew upon what they thought of as a global environmental ethic to legitimate their claims, the campaign was essentially locally based and locally driven. The protesters' spatialized enunciations of their protest, their direct actions, were in fact statements of local resistance to what were perceived as globalizing structures of power, in particular the structures of power that support private development at the expense of communal values, and allow local heterogeneity to be stifled by the homogenizing forces of economic rationalism.

While actual cultural differences may indeed be apparent in the responses of Aboriginal and non-Aboriginal people to the Skyrail, my point is that to see political practices as expression of cultural differences alone, is not only interpretively inadequate, but also operates to disenfranchise Aboriginal people by permitting them only to be cultural beings, and not political agents. It allows for strategic protest action on the part of Aboriginal people to be labelled unauthentic, thus effectively undermining any political force such action might have. Disputes such as the Skyrail are not expressions of given cultural differences. Rather they are situations in which discourses about such differences are contested and negotiated.

I developed my argument by highlighting a particular moment of protest within the Skyrail dispute. I argued that the Kuranda Skyrail dispute can best be understood as a performative production and articulation of sameness and difference, a dialectical

\footnotetext{
58. Moore 1994, p. 5.

59. Keith \& Pile 1993, p. 10.

60. See Henry 1994.
} 
play of identities. The Skyrail dispute produced moments of protest which allowed Aboriginal and non-Aboriginal residents of the Kuranda area to resist categorical identities and attempt to resolve the contradictions that such identities pose in the context of relationships to place that are contestable only because they are in fact shared.

As evidenced by the protest scene described above, in the performance of protest, actors not only challenge sameness by asserting their differences, but also, by engaging their differences, they refashion sameness, that is, their idea of 'community'. Such spatial enunciations of protest are about the negotiation and articulation of difference in the context of a collective articulation and situated practice of the social. The links I have described between the Skyrail dispute and the Djabugay native title claim reveals that this articulation of sameness and difference is not merely a matter of cultural values. In their political engagement with one another, people contest and negotiate categorical identities that are structurally and historically produced.

Rosita Henry teaches in the School of Anthropology and Archaeology at James Cook University. In 1999 she was awarded the PhD degree for her thesis, Practising place, performing memory: identity politics in an Australian town, the 'Village in the Rainforest'

\section{References}

Anderson, Christopher 1989, 'Aborigines and conservationism: the Daintree-Bloomfield road', Australian Journal of Social Issues, vol. 24, no. 3, pp. 214-227.

Bender, Barbara ed. 1993, Landscape: Politics and Perspectives, Providence.

Bhabha, Homi K. 1994, The Location of Culture, London.

Burnam Burnam 1987, 'Aboriginal Australia and the Green movement' in Green Poltics in Australia, ed. Drew Hutton, North Ryde, NSW, pp.91-104.

Butwin, J.M. 1978, 'Seditious laughter', Radical History Review, vol. 18, pp. 17-34.

Chow, Rey 1994, 'Where have all the natives gone?' in Displacements: Cultural Identities in Question, ed. A. Baumer, Bloomington, pp. 125-151.

Cuthbert, Denise and Grossman, Michele 1996, 'Trading places: locating the indigenous in the New Age', Thamyris, vol. 3, no. 1, pp. 18-36.

Duffin, Rhonda and Brim, Rosetta n.d., Ngapi Garrang Bulurru-m: All Things Come from Bulurru., Kuranda, Queensland.

Foucault, Michel 1988, 'The ethic of care for the self as a practice of freedom' in The Final Foucault, ed. J. Bernauer \& D. Rasmussen, Boston, pp. 1-20.

Fuary, Maureen M. 1992, 'Torres Strait and dawdhay: dimensions of self and otherness on Yam Island', paper presented at the Australian Anthropological Society Conference, Canberra, 30 September-2 October, 1992.

—. 1997, 'A novel approach to tradition: Torres Strait Islanders and Ion Idriess', Australian Journal of Anthropology, vol. 8, no. 3, pp. 247-258

Greer, Shelley and Henry, Rosita 1996. 'The politics of heritage:the case of the Kuranda Skyrail' in Heritage and Native Title: Anthropological and Legal Perspectives, ed. J. Finlayson and A. Jackson-Nakano, Canberra, pp.16-27.

Gunew, Sneja 1993, 'Feminism and the politics of irreducible differences: multiculturalism/ethnicity/race' in Feminism and the Politics of Difference, ed. S. Gunew \& A. Yeatman, St. Leonards, NSW, pp. 1-19. 
Gunew, Sneja and Yeatman, Anna, ed. 1993, Feminism and the Politics of Difference, St Leonards, NSW.

Henry, Rosita 1995, 'Environmental values and the politics of identity: the Kuranda Skyrail', Northern Radius, vol. 2, no. 2, pp. 6-8.

- 1999, Practising place, performing memory: identity politics in an Australian town, the 'Village in the Rainforest', PhD thesis, James Cook University, Townsville.

Jacobs, Jane 1994, 'Earth honouring: Western desires and indigenous knowledge', Meanjin, vol. 53, no. 2, pp. 305-14.

Jagose, Annamarie 1993, 'Slash and suture: post/colonialism in Borderlands/La Frontera: The New Mestiza' in Feminism and the Politics of Difference, ed. S. Gunew \& A. Yeatman, St. Leonards, NSW, pp. 212-227.

Kapferer, Bruce 1995, 'The performance of categories: plays of identity in Africa and Australia' in The Urban Context: Ethnicity, Social Networks, and Situational Analysis, ed. A. Rogers \& S. Vertovec, Oxford, pp 55-79.

Keith, M. and Pile, S. ed. 1993, 'Introduction part 1: the politics of place' in Place and the Politics of Identity, London, pp.1-21.

Kuchler, Susanne 1993, 'Landscape as memory: the mapping of process and its representation in a Melanesian society', in Landscape: Politics and Perspectives, ed. Barbara Bender, Oxford, pp.85-106.

Laclau, Ernesto and Mouffe, Chantal 1985, Hegemony and Socialist Srategy: Towards a Radical Democratic Politics, London.

Lattas, Andrew 1997, 'Aborigines and contemporary Australian nationalism: primordiality and the cultural politics of otherness' in Race Matters: Indigenous Australians and 'Our' Society, ed. G. Cowlishaw \& B. Morris, Canberra, pp. 223-225.

Lyotard, J. 1984, The Postmodern Condition: a Report on Knowledge, Manchester.

Marcus, Julie 1996, 'New age consciousness and Aboriginal culture: primitive dreaming in common places', Thamyris, vol. 3, no. 1, pp. 37-54.

- 1997, 'The journey out to the Centre: the cultural appropriation of Ayers Rock' inRace Matters: Indigenous Australians and 'Our' Society, ed. G. Cowlishaw \& B. Morris, Canberra, pp. 29-51.

Moore, Henrietta 1994, A Passion for Difference. Oxford.

Peters, John Durham 1997, 'Seeing bifocally: media, place, culture' in Culture, Power, Place: Explorations in Critical Anthropology, ed. A. Gupta and J. Ferguson, Durham, North Carolina, pp. 75-92.

Rubin, Charles T 1994, The Green Crusade: Rethinking the Roots of Environmentalism, New York.

Taussig, Michael 1993, Mimesis and Alterity: a Particular History of the Senses., London.

Thomas, Nicholas 1994, Colonialisms Culture: Anthropology, Travel and Government, Oxford.

Trigger, David S. 1996 'Contesting ideologies of natural resource development in British Colombia, Canada', Culture, vol. XVI, no. 1, pp. 55-69.

Turner, Terence 1991, 'Representing, resisting, rethinking: historical transformations of Kayapo culture and anthropological consciousness', in Colonial Situations: Essays 
on the Contextualization of Ethnographic Knowledge, ed. G. Stocking, Madison, pp. 285-313.

Turner, Victor 1982, 'Dramatic ritual/ritual drama: performative and reflexive anthropology' in A Crack in the Mirror: Reflexive Perspectives in Anthropology, ed. Jay Ruby, Philadelphia, pp. 83-97.

Sackett, Lee 1991, 'Promoting primitivism: conservationist depictions of Aboriginal Australians', Australian Journal of Anthropology, vol. 2, no. 2, pp. 233-46.

Sourial, M. 1994, 'Protesters, credible or farcical?' Cairns Post, 5 August, p. 8

Strang,Victoria 1997, Uncommon Ground: Cultural Landscapes and Environmental Issues, Oxford.

White, Bruce 1994, A Chronology of Documents, Letters, Media, and Events Telling the Story of How it is that a Cairns-Kuranda Cableway Got to Be Constructed in a Djabugay Cultural Landscape, Cairns. Manuscript in author's possession.

Young, Robert J.C. 1995, Colonial Desire: Hybridity in Theory, Culture and Race. London. 